\title{
PENGARUH KONDISI SOSIAL EKONOMI ORANG TUA TERHADAP HASIL BELAJAR IPS TERPADU SISWA
}

\author{
Palupi Hapsari ${ }^{1}$, Siti Maryam Yusuf ${ }^{2}$ \\ ${ }^{1}$ Institut Agama Islam Negeri Ponorogo, \\ Palupihap99@gmail.com \\ ${ }^{2}$ Institut Agama Islam Negeri Ponorogo, \\ maryam yusuf@yahoo.com
}

\section{ABSTRAK}

Lingkungan keluarga terutama orang tua merupakan dimensi yang paling penting dan utama. Untuk perkembangan anak baik perkembangan fisik maupun psikis. Jika kondisi sosial ekonomi orang tua baik dan cukup. Dari hasil penelitian sederhana ini dapat ditarik kesimpulan sebagai berikut: (1) Kondisi sosial ekonomi orang tua kelas 8 SMP Negeri 1 Sambit tahun pelajaran 2020/2021 secara umum dapat dikatakan dalam kategori sedang. yaitu dengan nilai persentase sebesar 63\%, (2) Hasil belajar ranah kognitif mata pelajaran IPS Terpadu siswa kelas 8 SMP Negeri 1 Sambit tahun ajaran 2020/2021 secara umum dapat dikatakan bahwa hasil belajar kognitif IPS Terpadu Mata pelajaran IPS siswa kelas 8 SMPN 1 Sambit berada pada kategori sedang yaitu dengan nilai persentase 70\%, (3) kondisi sosial ekonomi orang tua berpengaruh signifikan terhadap hasil belajar ranah kognitif SMP Negeri 1 Sambit tahun ajaran 2020/2021 ditunjukkan dengan nilai karena nilai signifikansi $0,000<0,05$ yang berarti gagal menolak $\mathrm{H}_{0}$. Kata kunci: Kondisi sosial ekonomi; hasil belajar.

\section{ABSTRACT}

The family environment, especially the parents, is the most important and main dimension. For children's development both physical and psychological development. If the socioeconomic conditions of the parents are good and sufficient. From the results of this simple research, the following conclusions can be drawn: (1) The socio-economic conditions of the class parents 8 SMP Negeri 1 Sambit in the academic year 2020/2021 in general can be said to be in the moderate category, namely with a percentage value of $63 \%$, (2) Learning outcomes in the cognitive domain of Integrated Social Studies subjects students grade 8 SMP Negeri 1 Sambit in the academic year 2020/2021 general it can be said that the cognitive learning outcomes of Integrated Social Studies subjects are grade 8 students of SMPN 1 Sambit is in the medium category, namely with a percentage value of $70 \%$, (3) the socioeconomic conditions of the parents are influential significant.for the results learning in the cognitive realm SMP Negeri 1 Sambit year 2020/2021 school year is indicated by a value because the significance value is $0.000<0.05$, which means that it fails to reject $H_{0}$.

\section{Keywords: Socio economic conditions, learning outcomes.}

\section{PENDAHULUAN}

Proses pendidikan tidak hanya dilakukan di lingkungan sekolah saja, tetapi dapat dilakukan di lingkungan keluarga. Dalam hal ini membuktikan bahwasannya kegiatan atau proses pendidikan dapat terjadi pada siapa saja, dimana saja, dan kapan saja. Pendidikan sendiri tidak semata-mata untuk meningkatkan kualitas intelegensia seseorang tetapi pendidikan juga memiliki tujuan mulia dengan membentuk seseorang menjadi generasi yang berbudi luhur, beradab, mandiri, dan bermartabat dengan mengedepankan nilai-nilai luhur yang telah ada dalam kehidupan masyarakat. Agar tujuan pendidikan dapat tercapai dengan baik maka diperlukan adanya suatu proses pendidikan yang mendukung sehingga input yang ada dapat menghasilkan 
output yang maksimal dan berkualitas sesuai dengan tujuan dari pendidikan. ${ }^{1}$ Proses disini dimaksudkan adalah suatu proses atau kegiatan belajar mengajar yang dilakukan di lingkungan sekolah dengan adanya bimbingan dan arahan dari seorang pendidik. Sekolah sendiri merupakan suatu lembaga pendidikan formal yang bersistem dan berstruktur dimana lembaga pendidikan ini memiliki tiga jenjang pendidikan yang meliputi pendidikan dasar, pendidikan menengah, dan pendidikan tinggi. Keberhasilan dalam kegiatan pembelajaran dapat dilihat dari hasil belajar siswa selama mengikuti kegiatan belajar mengajar di suatu lembaga pendidikan. ${ }^{2}$

Perkembangan pendidikan anak merupakan salah satu hal yang paling utama untuk mewujudkan cita-cita anak bangsa dan membentuk meraka menjadi insan yang berguna bagi nusa dan bangsa, dalam hal ini terdapat banyak faktor yang mempengaruhi anak untuk memperoleh kebutuhan dalam proses pendidikan sehingga mendukung prestasi belajar anak. Kondisi sosial ekonomi orang tua merupakan salah satu faktor yang dapat mempengaruhi hasil belajar siswa secara signifikan. Lingkungan keluarga khususnya orang tua memiliki peranan penting dalam menentukan keberhasilan belajar siswa, hal ini disebabkan karena orang tua merupakan lingkungan pertama bagi anak untuk mendapatkan perlindungan, bimbingan, kasih sayang dan arahan mengenai berbagai hal, baik tutur kata, berperilaku, pengetahuan dan sebagainya. Tugas orangtua adalah memberikan arahan, dukungan dan bimbingan dasar bagi perkembangan pendidikan anak.

Hasil Belajar siswa sendiri merupakan suatu pencapaian atau gambaran keberhasilan siswa dalam mengikuti proses kegiatan belajar mengajar yang dituangkan dalam bentuk nilai atau pensekoran. Hasil belajar meliputi kemampuan yang dimiliki dalam diri siswa setelah mendapatkan pengalaman, bimbingan dan pengajaran selama kegiatan pembelajaran yang dilakukan oleh pendidik. Sejumlah pengalaman yang diperoleh siswa dari kegiatan belajar yaitu mencangkup pada ranah kognitif (pengetahuan), afektif (sikap), dan psikomotorik (keterampilan). ${ }^{3}$ Tinggi rendahnya suatu nilai yang didapat siswa dalam proses kegiatan belajar merupakan suatu alat acuan untuk mengetahui seberapa jauh siswa memahami materi yang telah disampaikan dan memberikan suatu perubahan atau tidak dalam kegiatan pembelajaran, dalam hal ini hasil belajar yang dicapai siswa pasti memiliki suatu perbedaan tidak mungkin pencapaian belajar antara siswa satu dengan siswa lain sama rata, pasti terdapat perbedaan antara siswa satu dengan siswa yang lainnya.

Hasil belajar memiliki peranan yang sangat penting dalam proses belajar mengajar karena dengan adanya hasil belajar akan memberikan acuan dan informasi kepada guru tentang sejauh mana pemahaman siswa dalam menangkap materi dan kemajuan berfikir siswa untuk mencapai suatu tujuan belajar dengan adanya proses belajar mengajar (Sukmadinata, 2011: 102-103). ${ }^{4}$ Tercapainya keberhasilan belajar siswa dipengaruhi oleh faktor-faktor yang berasal dari dalam diri siswa, guru, sumber belajar, gaya belajar, fasilitas belajar, kondisi lingkungan dan lain sebagainya. Faktor yang mempengaruhi pencapaian keberhasilan belajar siswa dibagi menjadi dua yaitu faktor eksternal dan faktor internal. Kondisi sosial ekonomi orang tua merupakan salah satu faktor yang dapat mempengaruhi hasil belajar siswa secara signifikan. Dalam hal ini keadaan atau kondisi sosial ekonomi orang tua pastilah beragam (berbeda-beda), terdapat kondisi

\footnotetext{
${ }^{1}$ Indah Komsiyah, Belajar dan Pembelajaran (Yogyakarta: Teras, 2012), 56.

${ }^{2}$ Kadek Ari Prabawa, Pengaruh Kondisi Sosial Ekonomi dan Perhatian Orang Tua Terhadap Prestasi Belajar Ekonomi Siswa Kelas X4, (Jurnal: Pendidikan Ekonomi, Vol. 4 No. 1 Th 2017), 5.

${ }^{3}$ Purwanto, Evaluasi Hasil Belajar (Yogyakarta: Pustaka Belajar, 2012), 41.

${ }^{4}$ Sudjana Nana, Dasar-dasar Proses Belajar Mengajar (Bandung: Sinar Baru Algensindo, 2013), 105.
} 
sosial ekonomi keluarga yang tergolong baik dan cukup akan mampu menciptakan situasi yang baik bagi perkembangan pendidikan anak dan anggota keluarganya, ada pula kondisi sosial ekonomi orang tua yang tergolong kurang baik, dimana terdapat keterbatasan untuk menciptakan situasi yang baik bagi perkembangan pendidikan anak. Rangsangan terhadap anggota keluarga yang berstatus sosial ekonomi yang tinggi akan berbeda dengan yang berstatus sosial rendah, karena kondisi atau status tersebut akan berpengaruh besar terhadap kondisi psikologis dan pola pikir anak. Kondisi ekonomi orang tua cenderung menuntut orang tua untuk memfokuskan perhatiannya pada pemenuhan kebutuhan ekonomi sekaligus kebutuhan pendidikan bagi anaknya. $^{5}$

Kondisi sosial ekonomi orang tua berperan dalam keberhasilan belajar anak, terutama mempengaruhi prestasi belajar mereka. Kondisi ekonomi orang tua yang berkecukupan cenderung memberikan banyak pilihan kepada anak untuk dapat menikmati pendidikan dari pada pemenuhan kebutuhan sehari-hari, sehingga anak lebih terdorong dan bersemangat dalam proses pendidikan mereka. Tentunya semakin tinggi tingkat ekonomi orang tua, maka semakin tinggi pula motivasi anak sehingga akan lebih maksimal hasil yang dicapai. Oleh karena itu lingkungan keluarga khusunya orang tua harus mendukung penuh perkembangan pendidikan anak baik dari segi minat, bakat, pengetahuan, maupun keterampilannya dengan memberikan fasilitas atau kebutuhan yang diperlukan dalam proses pembelajaran sesuai dengan kemampuan orangtua.

Berdasarkan latar belakang di atas, maka tujuan penelitian kuantitatif ini adalah sebagai berikut: (1) Untuk mengetahui kondisi sosial ekonomi orangtua siswa kelas VIII SMPN 1 Sambit Ponorogo Tahun Ajaran 2020/2021, (2) Untuk mengetahui hasil belajar IPS Terpadu siswa kelas VIII SMPN 1 Sambit Ponorogo Tahun Ajaran 2020/2021, (3) Untuk mengetahui pengaruh signifikan antara kondisi sosial ekonomi orangtua terhadap hasil belajar IPS Terpadu siswa kelas VIII SMPN 1 Sambit Ponorogo Tahun Ajaran 2020/2021.

\section{METODE PENELITIAN}

Dalam penelitian ini pendekatan yang digunakan oleh peneliti adalah kuantitatif. Penelitian kuantitatif adalah metode penelitian yang berlandaskan pada filsafat positivism, yang digunakan untuk meneliti pada kondisi objek yang alamiah. Untuk menganalisis data yang dikumpulkan dengan menggunakan analisis regresi, analisis regresi merupakan model statistik yang digunakan untuk mempelajari pola hubungan logis antara dua variable atau lebih, dimana salah satu dari dua variable tersebut berfungsi sebagai variable terikat (dependent) dan variable bebas (independent).

Teknik pengumpulan data adalah suatu langkah yang penting dan paling utama dalam suatu penelitian, sebab tujuan utama dari teknik pengumpulan data dalam penelitian adalah untuk memperoleh atau mendapatkan data yang sesuai dengan lingkup penelitian. Tanpa adanya teknik pengumpulan data, maka peneliti tidak akan memperoleh informasi atau data yang memenuhi standar data yang telah ditetapkan dalam suatu penelitian. ${ }^{6}$ Adapun teknik pengumpulan data penelitian ini dengan menyebarkan kuisioner pada responden (siswa kelas VIII yang sudah dijadikan sampel dalam penelitian) yang terdiri dari 19 pertanyaan yang berkaitan dengan

\footnotetext{
${ }^{5}$ Parpto Aji Wibowo, Psikologi Pendidikan (Jakarta: PT Grafindo Raja, 2011), 156.

${ }^{6}$ Sugiyono, Metode Penelitian Pendidikan Pendekatan Kualitatif, Kuantitatif, dan R\&D (Bandung: Alfabeta, 2012), 308.
} 
kondisi sosial ekonomi orang tua, Angket yang digunakan dalam penelitian ini adalah angket tertutup, dimana angket yang diberikan kepada responden sudah diberikan alternatif jawaban dan responden hanya memberikan tanda silang pada salah satu jawaban yang sesuai. ${ }^{7}$ Untuk memudahkan peneliti menganalisis data, yang diperoleh dari angket bertingkat (rating scale) maka perlu diketahui skor atau jumlah yang diperoleh setiap responden dari hasil angket yang sudah terisi (Arikunto, 2006), dan menggunakan teknik dokumentasi ${ }^{8}$ Teknik ini digunakan untuk memperoleh data hasil belajar siswa kelas VIII SMPN 1 Sambit dari dokumen nilai raport khususnya pada mata pelajaran IPS Terpadu.

\section{Pengujian Instrumen Data}

Uji validitas menurut Arikunto ${ }^{9}$ menyatakan bahwa uji validitas merupakan suatu metode pengukuran yang menunjukkan tingkat kesahihan dari suatu instrument dalam penelitian. ${ }^{10}$ Rumus yang digunakan untuk mengukur instrumen kuisioner penelitian yang akan disebarkan kepada responden yang telah ditentukan, maka peneliti menggunakan rumus korelasi product moment, terdapat 19 item pertanyaan dalam penelitian ini dianggap valid. Hal tersebut dapat diketahui dari besarnya nilai $\mathrm{r}^{\text {hitung }}>\mathrm{r}^{\text {tabel }}$ dengan nilai siginifikansi sebesar 5\% atau $\mathrm{r}^{\text {hitung }}>0,23$ yy(dianggap valid). Oleh karena itu dapat dikatan dari 20 item pertanyaan yang disajikan, terdapat 19 pertanyaan yang valid dan 1 pertanyaan yang tidak valid mengenai kondisi sosial ekonomi orang tua.

Tahap selanjutnya melakukan uji reliabilitas. Menentukan tingkat reliabilitas intrumen penelitian berpedoman dari pendapat Suharsimi. Uji reliabilitas digunakan untuk mengukur sejauh mana suatu alat ukur bisa dipercaya untuk digunakan sebagai alat pengumpulan data. Berikut adalah rumus koefesien alpha cronbach. Berdasarkan hasil uji reliabilitas terhadap instrumen kondisi sosial ekonomi orang tua pada tabel 3.5 dapat diketahui bahwa instrumeninstrumen dalam angket tersebut dinyatakan reliabel, hal ini diketahui dari besarnya nilai Cronbach Alpha $>\mathrm{r}^{\text {tabel }}$ dengan nilai siginifikansi sebesar 5\% atau 0,888 $>0,235$.

\section{Teknik Analisis Data}

Dalam suatu penelitian kuantitatif analisis data merupakan suatu meytode yang ditujukan untuk menganalisis informasi atau data-data yang diperoleh dari suatu penelitian. Metode menganalisis data ini merupakan suatu proses yang sangat penting dalam kegiatan penelitian. Seperti yang telah dipaparkan oleh Patton, menyatakan bahwa analisis data adalah suatu langkah atau tahapan untuk mengatur proses urutan data, mengorganisasikan dalam satu pola, dan menjadi urutan dasar. ${ }^{11}$

Teknik analisis data dalam penelitian kuantitatif menggunakan statistik. Terdapat dua macam statistik yang digunakan dalam analisis data penelitian, yaitu statistik deskriptif dan statistik inferensial. Statistik inferensial meliputi statistik parametris dan statistik nonparametris. ${ }^{12}$ Teknik anaylisis data yang digunakan dalam penelitian ini adalah dengan menggunakan statistik deskriptif dan statistik inferensia parametris

\footnotetext{
${ }^{7}$ Sukardi, Metodologi Penelitian Pendidikan (Jakarta: PT Bumi Aksara, 2013), 149.

${ }^{8}$ Ibid., 195.

${ }^{9}$ Nana Sayodih Sukamdinata, Metode Penelitian Pendidikan (Bandung: Remaja Rosdakarya, 2009), 220.

${ }^{10}$ Syofian Siregar, Statistik Parametrik untuk Penelitian Kuantitatif, (Jakarta: PT Fajar, 2013), 75.

11 Sugiono, Metode Penelitian pendidikan (Bandung: alfabeta, 2014), 114.

12 Mardalis, Metode Penelitian Kuantitatif, (Jakarta: Bumi Aksara, 2012), 67.
} 
Analisis deskriptif dilakukan untuk mendeskripsikan, menggambarkan, dan menganalisis data yang diperoleh dari masing-masing variabel penelitian. Dalam analisis deskriptif ini penulis menggunakan rumus mean, standard deviasi dan prosentase untuk mengetahui jumlah interval dan prosentase skor yang ada melalui hasil angket atau kuisioner mengenai kondisi sosial ekonomi orang tua. Analisis statistik deskriptif berguna untuk memaparkan dan menggambarkan data penelitian, mencakup; jumlah data, nilai maksimal, nilai minimal, nilai rata-rata, modus dan standar deviasi.

Analisis inferensia merupakan analisis yang dilakukan untuk mengetahui data yang diperoleh dari sampel yang sudah ditentukan dan hasilnya ditujukan atau diberlakukan untuk populasi secara keseluruhan dalam suatu penelitian. Analisis inferensia dalam penelitian ini dilakukan untuk mengetahui hubungan atau pengaruh antara dua variabel yang berbeda, dalam hal ini peneliti melakukan uji regresi linier sederhana. Untuk uji regresi linier sederhana harus terpenuhi beberapa syarat seperti: item-item dalam instrument penelitian harus valid dan reliabel, serta sampel berasal dari populasi yang terdistribusi normal oleh karena itu terlebih dahulu harus dilakukan uji validitas, uji reliabilitas, dan uji normalitas data, uji linieritas, uji heteroskedastitas. ${ }^{13}$

\section{HASIL DAN PEMBAHASAN}

\section{Uji Analisis Data}

\section{1) Uji Normalitas}

Uji normalitas yang digunakan peneliti dalam menganalisis data menggunakan uji Kolmogorov-Smirnov dengan bantuan aplikasi SPSS versi 25. Dalam uji ini peneliti menggunakan nilai signifikansi sebesar 5\%. Berikut data hasil uji normalitas yang telah dilakukan oleh peneliti dalam tabel berikut ini:

Tabel 4.10

Data Uji Normalitas One-Sample Kolmogorov-Smirnov Test

\begin{tabular}{|l|r|r|}
\hline & & Unstandardized Residual \\
\hline $\mathrm{N}$ & Mean & 70 \\
Normal Parameters $\mathrm{a}, \mathrm{b}$ & Std. &, 0000000 \\
& Deviation & 3.68928543 \\
& Absolute & \\
Most Extreme Differences & Positive & .079 \\
& Negative & .079 \\
Kolmogorov-Smirnov Z & & -.050 \\
Asymp. Sig. (2-tailed) & & .079 \\
\hline
\end{tabular}

a. Test distribution is Normal.

b. Calculated from data.

Hasil perhitungan tersebut menunjukan jika uji normalitas untuk variabel $\mathrm{X}$ dan $\mathrm{Y}$ menggunakan kolmogorov-sminov test diperoleh nilai signifikan 0,200 yang artinya lebih 
besar dari alpha 0,05 maka artinya data tersebut berdistribusi normal dan dapat dilanjutkan untuk pengujian selanjutnya.

\section{2) Uji Linieritas}

Mengetahui data yang kita memiliki bersifat linier atau tidaknya maka perlu dilakukan uji linieritas. Pengujian ini menggunakan SPSS 21 dengan signifikan deviation from linearity lebih dari 0,05 maka data tersebut dikatakan linier. ${ }^{14}$

Tabel 4.11

Data Uji Linieritas

ANOVA Table

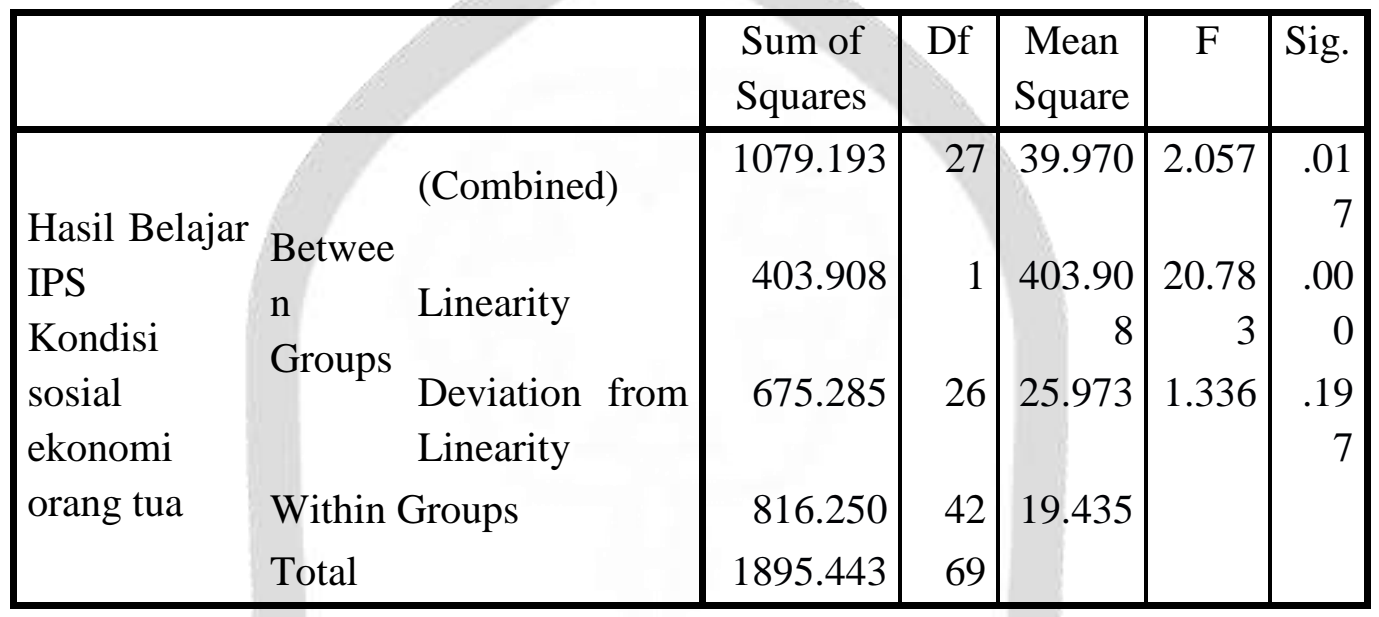

Nilai sig pada baris linierity adalah $0,000<0,05$ yang artinya bahwa hubungan antara variabel bebas dan variabel terikat berarti. Untuk uji linieritas diperhatikan nilai sig pada baris Deviation From Linierity, dari hasil uji diatas nilai sig pada baris Deviation From Linierity adalah $0,197>0,05$ yang artinya bahwa arah regresi dari variabel bebas ke variabel terikat bersifat linier.

\section{3) Uji Autokorelasi}

Pada penelitian ini untuk menguji ada tidaknya gejala autokorelasi menggunakan uji Durbin Waston, dengan bantuan aplikasi SPSS versi 25. Dalam uji ini peneliti menggunakan nilai signifikansi sebesar 5\%.

Tabel 4.12

Data Uji Autokorelasi

\begin{tabular}{|l|l|l|l|l|l|}
\hline Model & $\mathrm{R}$ & R Square & $\begin{array}{l}\text { Adjusted R } \\
\text { Square }\end{array}$ & $\begin{array}{l}\text { Std. Error of } \\
\text { the Estimate }\end{array}$ & $\begin{array}{l}\text { Durbin } \\
\text { Waston }\end{array}$ \\
\hline 1 & .462 & .213 & .202 & 4.683 & 1.814 \\
\hline
\end{tabular}

${ }^{14}$ Budiyono, Statistik Untuk Penelitian (Surakarta: UNS Press, 2016), 156. 
Pada tabel model summaru menunjukkan bahwa nilai Durbin Waston atau nilai d sebesar 1,814 .

Tabel 4.13

Tabel Hasil Uji Autokorelasi

\begin{tabular}{|c|c|c|c|c|}
\hline $\mathrm{D}$ & $\mathrm{Dl}$ & $\mathrm{Du}$ & $4-\mathrm{dl}$ & $4-\mathrm{du}$ \\
\hline 1,814 & 1,583 & 1,641 & 2,417 & 2,359 \\
\hline
\end{tabular}

$$
\begin{aligned}
\text { Hasil } & =\mathrm{du}<\mathrm{d}<(4-\mathrm{du}) \\
& =1,641<1,814<2,359
\end{aligned}
$$

Maka dapat disimpulkan bahwa tidak terjadi autokorelasi

\section{Uji Hipotesis}

1) Analisis Data Mengenai Kondisi Sosial Ekonomi Orangtua Siswa Kelas VIII SMP Negeri 1 Sambit Tahun Pelajaran 2020/2021.

Hipotesis pertama adalah mengetahui kondisi sosial ekonomi orang tua siswa, setelah peneliti menyebar dan mengetahui jumlah kuisioner, selanjutnya mengetahui nilai Mean (Mx) dan Standart Deviasi (SDx) dari data yang sudah didapat sebelumnya.

\section{Tabel 4.6}

\section{Hasil Mean dan Standart Deviasi Variabel X}

\begin{tabular}{|l|l|}
\hline Deskripsi & Nilai \\
\hline Mean (rata-rata) & 60,31 \\
\hline Standar deviasi & 7,666 \\
\hline Skor minimum & 42 \\
\hline Skor maxsimum & 74 \\
\hline N & 70 \\
\hline
\end{tabular}

Berikut perhitungan untuk menentukan kategori dari kondisi Social ekonomi orang tua siswa kelas VIII SMP Negeri 1 Sambit Ponorogo:

a) $\mathrm{Mx}+1$. $(\mathrm{SDx})=60,31+1 \cdot(7,666)$

b) $\mathrm{Mx}-1 .(\mathrm{SDx}) \quad=60,31-1 \cdot(7,666)$

$$
\begin{aligned}
& =60,31+7,666 \\
& =67,976=68 \text { (dibulatkan) }
\end{aligned}
$$

$$
\begin{aligned}
& =60,31-7,666 \\
& =52,644=53(\text { dibulatkan })
\end{aligned}
$$

c) Antara $\mathrm{Mx}+$ 1.(SDx) sampai dengan $\mathrm{Mx}-1$. (SDx) 
Dari perhitungan tersebut diketahui bahwa skor atau nilai lebih tinggi dari 68 dapat digolongkan dalam kondisi sosial ekonomi orang tua siswa kelas VIII tinggi, skor atau nilai kurang dari 53 dapat digolongkan dalam Kondisi social ekonomi orang tua siswa kelas VIII rendah, dan skor atau nilai antara 68-53 digolongkan dalam kondisi sosial ekonomi otangtua siswa kelas VIII sedang.

Tabel 4.7

Klasifikasi Kondisi Sosial Ekonomi Orang Tua.

\begin{tabular}{|c|c|c|c|c|}
\hline Nomor & Nilai & Skor & P & Golongan \\
\hline 1 & $>68$ & 13 & $\frac{13}{70} \times 100=18,5 \%$ & Tinggi \\
\hline 2 & $68-53$ & 44 & $\frac{44}{70} \times 100=63 \%$ & Sedang \\
\hline 3 & $<53$ & 13 & $\frac{13}{70} \times 100=18,5 \%$ & Rendah \\
\hline \multicolumn{2}{|c|}{ Jumlah } & 70 & $100 \%$ & \\
\hline
\end{tabular}

Dari klasifikasi data tersebut dapat dilihat, bahwa kondisi sosial ekonomi orang tua kelas VIII SMP Negeri 1 Sambit Ponorogo termasuk dalam golongan tinggi dengan nilai F sebanyak 13 responden dengan nilai $\mathrm{P}$ (Prosentase) sebesar 18,5\%, termasuk dalam golongan sedang dengan nilai $\mathrm{F}$ sebanyak 44 responden dengan nilai $\mathrm{P}$ (Prosentase) sebesar $63 \%$, serta dalam golongan rendah dengan nilai $\mathrm{F}$ sebanyak 13 responden dengan nilai $\mathrm{P}$ (Prosentase) sebesar 18,5\%. Oleh karena itu dapat disimpulkan, bahwa kondisi sosial ekonomi orang tua siswa kelas VIII SMP Negeri 1 Sambit Ponorogo Tahun Ajaran2020/2021 secara garis besar tergolong dalam kategori sedang yaitu sebesar $63 \%$.

Dari hasil perolehan data diatas menunjukkan bahwa kondisi sosial ekonomi orang tua siswa kelas VIII SMP Negeri 1 Sambit tergolong cukup baik untuk memenuhi dan membiayai segala kebutuhan pendidikan siswa, dan dapat memberikan fasilitas-fasilitas yang dibutuhkan oleh siswa untuk menunjang adanya kegiatan pembelajaran yang efektif dan perkembangan pendidikan anak agar anak terdorong motivasi belajarnya sehingga anak anak lebih berkonsentrasi pada prestasi belajarnya, karena telah diberikan berbagai fasilitasfasilitas yang menunjang adanya kegaiatan pembelajaran baik di lingkungan sekolah maupun di lingkungan rumah.

\section{2) Analisis Data Mengenai Hasil Belajar IPS Terpadu Siswa Kelas VIII SMP Negeri 1 Sambit Ponorogo Tahun Ajaran 2020/2021}

Hipotesis ke dua adalah untuk mengetahu hasil belajar IPS terpadu. Setelah peneliti mengetahui nilai pengetahuan dari masing-masing responden yang sudah dijadikan sebagai sampel oleh peneliti, selanjutnya mencari nilai Mean (Mx) dan Standart Deviasi (SDx) dari data yang sudah diperoleh sebelumnya. 
Tabel 4.8

Nilai Mean dan Standart Deviasi Variabel Y

\begin{tabular}{|c|c|}
\hline Deskripsi & Nilai \\
\hline Mean (rata-rata) & 77,74 \\
\hline Standar deviasi & 5,075 \\
\hline Skor minimum & 68 \\
\hline Skor maxsimum & 90 \\
\hline $\mathrm{N}$ & 70 \\
\hline
\end{tabular}

Berikut perhitungan untuk menentukan kategori dari hasil belajar siswa kelas VIII SMP Negeri 1 Sambit Ponorogo:

a) $\mathrm{Mx}+1 .(\mathrm{SDx}) \quad=77,74+1 \cdot(5,075)$

$$
\begin{aligned}
& =77,74+5,075 \\
& =82,815=83 \text { (dibulatkan) }
\end{aligned}
$$

b) $\mathrm{Mx}-1 .(\mathrm{SDx}) \quad=77,74-1$.

$$
\begin{aligned}
& =77,74-5,075 \\
& =72,665=73 \text { (dibulatkan) }
\end{aligned}
$$

c) Antara $\mathrm{Mx}+1$. $(\mathrm{SDx})$ dan $\mathrm{Mx}-1$.(SDx)

Dari perhitungan tersebut menunjukkan bahwa nilai lebih tinggi dari 83 dapat digolongkan dalam hasilbelajar siswa kelas VIII tinggi, sedangkan nilai kurang dari 73 dapat dikategorikan dalam hasil belajar siswa kelas VIII rendah, dan skor atau nilai antara 83-73 dikategorikan dalam hasil belajar siswa kelas. VIII sedang.

Tabel 4.9

Klasifikasi Hasil Belajar IPS Terpadu Siswa Kelas VIII

\begin{tabular}{|c|c|c|c|c|}
\hline Nomor & Nilai & Jumlah & P & Kategori \\
\hline 1 & $>83$ & 12 & $\frac{12}{70} \times 100=17 \%$ & Tinggi \\
\hline 2 & $83-73$ & 49 & $\frac{49}{70} \times 100=70 \%$ & Sedang \\
\hline 3 & $<73$ & 9 & $\frac{9}{70} \times 100=13 \%$ & Rendah \\
\hline \multicolumn{2}{|c|}{ Jumlah } & 70 & $100 \%$ & \\
\hline
\end{tabular}

Dari klasifikasi data diatas dapat diketahui bahwa hasil belajar pada mata pelajaran IPS Terpadu siswa kelas VIII SMP Negeri 1 Sambit Ponorogo dalam golongan tinggi dengan nilai $\mathrm{F}$ sebanyak 12 responden dengan nilai $\mathrm{P}$ (Prosentase) sebesar $17 \%$, dalam golongan sedang dengan nilai $\mathrm{F}$ sebanyak 49 responden dengan nilai prosentase 
sebesar 70\%, dan dalam golongan rendah dengan nilai $\mathrm{F}$ sebanyak 9 responden dengan nilai P (Prosentase) sebesar 13\%. Dengan demikian dapat disimpulkan secara umum bahwa hasil belajar mata pelajaran IPS Terpadu siswa kelas VIII SMPN 1 Sambit Ponorogo Tahun Ajaran 2020/2021 secara garis besar tergolong dalam kategori sedang yaitu sebesar $70 \%$.

Hal ini menunjukkan bahwa terdapat motivasi belajar dalam diri siswa yang ditunjukkan dengan hasil belajar ranah kognitif baik. Tercapainya hasil belajar yang baik ini tentu dipengaruhi oleh beberapa faktor yang dapat mendorong motivasi belajar dalam diri siswa salah satunya adalah faktor kondisi sosial ekonomi orang tua. Diketahui dari nilai prosentase kondisi sosial ekonomi orang tua sebesar $67 \%$ yang tergolong dalam kategori cukup baik juga berdampak pada hasil belajar ranah kognitif siswa yang cukup baik pula, dimana lingkungan keluarga khususnya kedua orang tua mampu memberikan perhatian penuh terhapad kebutuhan anaknya dimana orang tua dapat membiayai, memenuhi, dan memberikan segala kebutuhan pendidikan dan fasilitas-fasilitas yang menunjang kegiatan pembelajaran, baik di lingkungan sekolah maupun di lingkungan rumah, sehingga anak juga akan lebih termotivasi dan terdorong untuk giat belajar dan meningkatkan kemampuannya dari hari ke hari sehingga tercapinya prestasi belajar yang baik di sekolah.

\section{3) Pengaruh Kondisi Sosial Ekonomi Orangtua Terhadap Hasil Belajar IPS Terpadu Siswa Kelas VIII SMPN 1 Sambit Ponorogo Tahun Ajaran 2020/2021 \\ Regresi Linier Sederhana.}

Pada uji regresi linier sederhana ini peneliti menggunakan alat bantu perhitungan (SPSS versi 25). Berikut ini data atau hasil uji regresi linier sederhana:

Tabel 4.15 Tabel Anova

ANOVA $^{\mathrm{a}}$

\begin{tabular}{|rl|r|r|r|r|r|}
\hline Model & & Sum of Squares & Df & Mean & F & Sig. \\
\hline \multirow{4}{*}{1} & Regressio & 838,224 & 1 & 838,224 & 60,693 &, $000^{\mathrm{b}}$ \\
$\mathrm{n}$ & & & & & & \\
& Residual & 939,147 & 68 & 13,811 & & \\
& Total & 1777,371 & 69 & & & \\
\hline
\end{tabular}

a. Dependent Variable: Hasil Belajar IPS Terpadu

b. Predictors: (Constant) Kondisi Sosial Ekonomi Orang Tua

Dari hasil data tersebut menunjukkan bahwa $F_{\text {hitung }}=60,693$ dengan nilai signifikansi < nilai probabilitas, berarti $(0,000<0,05)$ dengan demikian model regresi diatas dapat digunakan untuk menganalisis variable $X$. Selanjutnya guna menguji apakah variable $X$ berpengaruh terhadap variable $\mathrm{Y}$, dapat dilakukan langkah pengujian menggunakan nilai $\mathrm{F}$ dari perhitungan tabel ANOVA di atas. 
Berdasarkan output tersebut menunjukkan bahwa, nilai F $F_{\text {hitung }}$ dari tabel ANOVA lebih besar > dari nilai $\mathrm{F}_{\text {tabel }}(60,693>3,98)$ maka dapat disimpulkan $\mathrm{H}_{0}$ ditolak dan $\mathrm{H}_{1}$ diterima, yang berarti variable $\mathrm{X}$ (kondisi sosial ekonomi orangtua) berpengaruh terhadap variabel $\mathrm{Y}$ (hasil belajar).

Tabel 4.16

\section{Tabel Coefficients}

\section{Coefficients $^{\mathrm{a}}$}

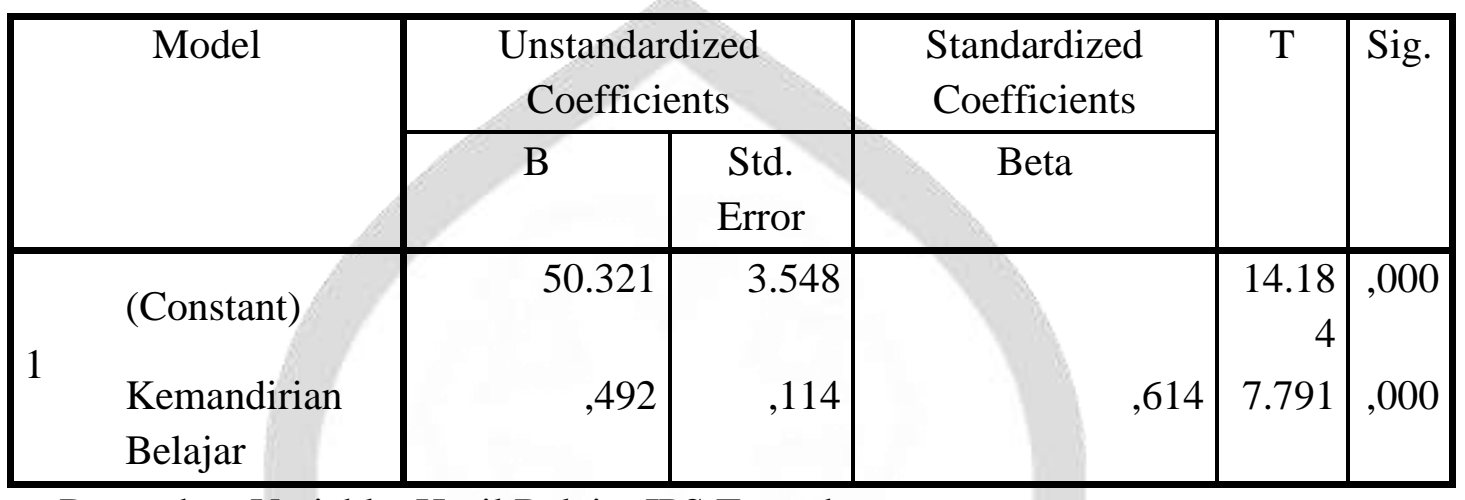

a. Dependent Variable: Hasil Belajar IPS Terpadu

Pengujian Coefficients diatas mendapatkan hasil:

$$
\begin{aligned}
& Y=a+b X \\
& Y=50,321+0,455 X
\end{aligned}
$$

Nilai konstan menunjukkan sebesar 50,321 yang berarti menyatakan bahwa apabila kondisi sosial ekonomi orang tua dianggap konstan maka hasil belajar ranah kognitif sebesar 50,321. Koefisien regresi kondisi sosial ekonomi orangtua sebesar 0,455 menunjukkan bahwa apabila kondisi sosial ekonomi orang tua dinaikkan satu point maka akan memiliki pengaruh sebesar 0,455 terhadap hasil belajar ranah kognitif. Oleh karena itu dapat disimpulkan bahwa kondisi sosial ekonomi orang tua memiliki peranan sebesar 0,455 terhadap hasil belajar ranah kognitif. Koefisien regresi tersebut memiliki nilai positif, sehingga dapat dikatakan bahwa arah variabel $\mathrm{X}$ kondisi sosial ekonomi orang tua terhadap variabel Y hasil belajar ranah kognitif adalah positif.

Variabel $\mathrm{X}$ memiliki arah positif terhadap variabel $\mathrm{Y}$ hal ini berarti lingkunga keluarga orang tua dapat memenuhi berbagai kebutuhan dan fasilitas-fasilitas pembelajaran yang menunjang adanya proses pendidikan baik itu di lingkungan rumah maupun di lingkungan sekolah, sehingga anak akan terdorong dan lebih termotivasi dengan sendirinya untuk terus giat belajar dan meningkatkan prestasi nya disekolah, tentunya hal tersebut telah didukung dengan berbagai fasilitas pembelajaran yang telah disediakan oleh orang tua. 
Tabel 4.17

Tabel Model Summary

Model Summary ${ }^{b}$

\begin{tabular}{|c|c|c|c|c|}
\hline Model & $\mathrm{R}$ & $\begin{array}{c}\mathrm{R} \\
\text { Square }\end{array}$ & $\begin{array}{c}\text { Adjusted R } \\
\text { Square }\end{array}$ & Std. Error of the Estimate \\
\hline 1 &, $687^{\mathrm{a}}$ &, 472 &, 464 & 3,716 \\
\hline
\end{tabular}

a. Predictors: (Constant), Kondisi Sosial Ekonomi Orang Tua

b. Dependent Variable: Hasil Belajar IPS Terpadu

Nilai R Square sebesar 0,472 dimana jumlah atau nilai tersebut menunjukkan bahwa pada variabel X (kondisi sosial ekonomi orangtua) memiliki nilai prosentase yaitu sebesar 47,2\% terhadap hasil belajar ranah kognitif pada mata pelajaran IPS terpadu siswa kelas VIII SMPN 1 Sambit Ponorogo Tahun Ajaran 2020/2021. Berdasarkan nilai prosentase diatas menunjukkan bahwa kondisi sosial ekonomi orang tua berpengaruh sebesar 47,2\% terhadap variabel Y hasil belajar ranah kognitif pada mata pelajaran IPS terpadu siswa kelas VIII SMP Negeri 1 Sambit tahun pelajaran 2020/2021 dan 52,8\% dipengaruhi oleh sebab-sebab lain yang berdampak sekaligus memberikan pengaruh terhadap hasil belajar siswa yang tidak berkaitan dengan apa yang peneliti teliti di penelitian ini.

\section{PENUTUP}

Dari data penelitian yang didapat dari data hasil analisis, peneliti dapat mengemukakan kesimpulan sebagai berikut: Kondisi sosial ekonomi orang tua kelas 8 SMP Negeri 1 Sambit tahun pelajaran 2020/2021 secara umum dapat dikatakan dalam kategori sedang yaitu dengan nilai prosentase sebesar 63\%, hal tersebut menunjukkan kondisi sosial ekonomi orang tua siswa kelas 8 SMPN 1 Sambit tergolong cukup baik untuk memenuhi segala kebutuhan yang berkaitan dengan proses pendidikan, dan dapat memberikan fasilitas-fasilitas yang dibutuhkan oleh siswa untuk menunjang adanya kegaiatan pembelajaran yang efektif.

Hasil belajar IPS Terpadu siswa kelas 8 SMP Negeri 1 Sambit tahun pelajaran 2020/2021 secara umum dapat dikatakan bahwa hasil belajar ranah kognitif mata pelajaran IPS Terpadu t siswa kelas 8 SMPN 1 Sambit adalah dalam kategori sedang yaitu dengan nilai prosentase $70 \%$. Tercapainya hasil belajar yang baik ini tentu pengaruhi oleh faktor kondisi sosial ekonomi orang tua yang cukup baik pula, dimana orang tua mampu memberikan segala kebutuhan pendidikan dan fasilitas pembelajar maka anak juga akan lebih termotivasi untuk giat belajar dan meningkatkan kemampuannya dari hari ke hari.

Setelah mengetahui nilai regresi linier sederhana, dengan nilai signifikansi sebesar 5\% $(0,05)$ maka dalam regresi linier sederhana variabel independen (kondisi sosial ekonomi orangtua) terhadap variabel dependen (hasil belajar ranah kognitif mata pelajaran IPS Terpadu siswa kelas 8 SMP Negeri 1 Sambit tahun pelajaran 2020/2021) gagal tolak $\mathrm{H}_{0}$ karena nilai signifikansi $0,000<0,05$. Adanya pengaruh yang signifikan antara kondisi sosial ekonomi orang tua terhadap hasil belajar IPS Terapdu siswa kelas 8 SMPN 1 Sambit tahun ajaran 2020/2021. Hal tersebut ditunjukkan dengan kondisi sosial ekonomi orang tua siswa kelas VIII SMPN 1 Sambit yang tergolong dalam kategori cukup baik (sedang) yang mana orang tua siswa mampu mencukupi segala kebutuhan pendidikan anaknya dan menunjang segala fasilitas yang 
dibutuhkan dalam kegiatan pembelajaran hal tersebut tentu berpengaruh terhadap hasil belajar ranah kognitif siswa.

\section{DAFTAR PUSTAKA}

Komsiyah Indah. (2012). Belajar dan Pembelajaran. Yogyakarta: Teras.

Purwanto. (2012). Evaluasi Hasil Belajar. Yogyakarta: Pustaka Belajar.

Nana Sudjana. (2013). Dasar-dasar Proses Belajar Mengajar. Bandung: Sinar Baru Algensindo.

Sugiyono. (2012). Metode Penelitian Pendidikan Pendekatan Kualitatif, Kuantitatif, dan R\&D. Bandung: Alfabeta.

Sukamdinara Nana Sayodih. (2009). Metode Penelitian Pendidikan. Bandung: Remaja Rosdakarya.

Syofian Siregar. (2013). Statistik Parametrik untuk Penelitian Kuantitatif. Jakarta: PT Fajar.

Sugiono. (2014). Metode Penelitian pendidikan. Bandung: alfabeta.

Mardalis. (2012). Metode Penelitian Kuantitatif. Jakarta: Bumi Aksara.

Budiyono. (2016). Statistik Untuk Penelitian. Surakarta: UNS Press.

Wibowo Aji Prapto (2011). Psikologi Pendidikan, Jakarta: PT Grafindo Raja. 